\title{
ZnO Films Deposited on Glass by Means of DC Sputtering
}

\author{
Masato Ohmukai1, Takuya Nakagawa², Ayumu Matsumoto ${ }^{3}$ \\ ${ }^{1}$ Department of Electrical and Computer Engineering, Akashi College of Technology, Akashi, Japan \\ ${ }^{2}$ Technical Education Support Center, Akashi College of Technology, Akashi, Japan \\ ${ }^{3}$ Collaborative Laboratories for Advanced Decommissioning Science, Japan Atomic Energy Agency, Ibaraki, Japan \\ Email:ohmukai@akashi.ac.jp
}

How to cite this paper: Ohmukai, M., Nakagawa, T. and Matsumoto, A. (2016) $\mathrm{ZnO}$ Films Deposited on Glass by Means of DC Sputtering. Journal of Materials Science and Chemical Engineering, 4, 1-7.

http://dx.doi.org/10.4236/msce.2016.410001

Received: September 8, 2016

Accepted: October 7, 2016

Published: October 10, 2016

Copyright $\odot 2016$ by authors and

Scientific Research Publishing Inc.

This work is licensed under the Creative

Commons Attribution International

License (CC BY 4.0).

http://creativecommons.org/licenses/by/4.0/

\begin{abstract}
$\mathrm{ZnO}$ films were deposited on glass substrates by means of a direct current (DC) sputtering technique. The physical properties of the films were investigated on the basis of X-ray diffraction measurements. It was found that as-deposited films show c-axis oriented crystal normal to the surface with the extension of $c$ axis by $1.27 \%$ that is estimated from the shift of the peak in the X-ray diffraction pattern. Postdeposition annealing in air at higher than $400^{\circ} \mathrm{C}$ eliminates the shift and sharpens the diffraction peak structure at the same time. The electrical resistivity continues to decrease from $500 \Omega \cdot \mathrm{cm}$ down to $0.6 \Omega \cdot \mathrm{cm}$ by annealing as high as $600^{\circ} \mathrm{C}$.
\end{abstract}

\section{Keywords}

ZnO Film, DC Sputtering, Annealing, X-Ray Analysis

\section{Introduction}

$\mathrm{ZnO}$ has a long history of its research but the study in the scope of electronic device application has been made in comparatively recent years. Epitaxial growth of $\mathrm{ZnO}$ on sapphire was reported no earlier than 1970s [1]. It is partly because the control of the stoichiometry between $\mathrm{Zn}$ and $\mathrm{O}$ is difficult. It has been commonly accepted that oxygen vacancy and zinc interstitial defects are natively introduced [2], [3].

Many kinds of compound semiconductors such as GaAs, InP and GaN are nowadays playing an important role in the semiconductor field. In this circumstance, $\mathrm{ZnO}$ attracts more and more attention because of a direct wide band gap of $3.3 \mathrm{eV} \mathrm{[4].} \mathrm{On} \mathrm{the}$ other hand, $\mathrm{ZnO}$ is expected to be a transparent conductor replaced by indium tin oxide [5]. $\mathrm{ZnO}$ is also an attractive material to solar cell [6], liquid crystal display [7] and spintronics [8]. Thin film transistors are now developed with $\mathrm{ZnO}$ [8]. 
As for the deposition methods, various deposition techniques have been challenged such as radio frequency (rf) sputtering [9], [10], molecular beam epitaxy [11], [12], pulsed laser deposition [13], [14] and chemical vapor deposition [15], [16]. We are engaged in $\mathrm{ZnO}$ deposition using direct current (DC) sputtering with $\mathrm{ZnO}$ target. The DC sputtering is well known as an excellent method for metal deposition, but not so much for compound materials. The advantage of the DC sputtering is the simplicity of the apparatus; it does not require any radio frequency system. The technique has not been widely applied with exception of the DC sputtering of zinc target under oxygen atmosphere [17], [18]. The $\mathrm{ZnO}$ target has been very recently investigated in DC sputtering deposition experiments [19]-[22].

It was reported [23] that $\mathrm{ZnO}$ was deposited on Si substrate by a DC sputtering method. The interesting results were obtained that excess oxygen was included in the deposited film to stoichiometric $\mathrm{ZnO}$ on the basis of X-ray diffractometry and energy dispersive $\mathrm{X}$-ray spectroscopy. The excess vanishes through post-deposition annealing above $400^{\circ} \mathrm{C}$. In this article, we focus on the $\mathrm{ZnO}$ deposition on glass substrates.

\section{Experimental Details}

In this experiment, a $\mathrm{ZnO}$ ceramic target round disk $(4 \mathrm{~N})$ with $70 \mathrm{~mm}$ in diameter was used. A substrate of borosilicate glass plate (S1225 by Matsunami Glass Ind., LTD.) was installed at a distance of $30 \mathrm{~mm}$ from the target.

The deposition was performed for an hour under the ambient pressure of 7.5 $\mathrm{Pa}$ and input power of $24 \mathrm{~W}$. The substrate was not intentionally heated during the deposition. After the deposition was completed, annealing was performed by an electric furnace at $200^{\circ} \mathrm{C}, 400^{\circ} \mathrm{C}$ and $600^{\circ} \mathrm{C}$ for half an hour in the air. The annealing temperature was not raised above $600^{\circ} \mathrm{C}$ in order not to soften the glass substrate.

The obtained samples were examined by means of an X-ray diffraction (XRD) measurement. The XRD pattern was taken with a spectrometer (Ultima IV, Rigaku) equipped with a $\mathrm{Cu}$ target and a Ni filter. An X-ray tube was loaded with $40 \mathrm{kV}$ and 40 $\mathrm{mA}$ in the experiment. The resistivity of the deposited films was analyzed by means of the van der Pauw method.

\section{Results and Discussion}

The XRD patterns taken from both as-deposited and annealed $\left(600^{\circ} \mathrm{C}\right)$ samples were shown in Figure 1. Both samples have shown single peak structure around 34.48 degree that is assigned to the diffraction from (002) plane of $\mathrm{ZnO}$. Four other main peaks at 31.8, 36.5, 47.5 and 57.1, corresponding to (100), (101), (102) and (110) planes of $\mathrm{ZnO}$, were not observed. This suggests the preferred orientation during the growth in such a way that $\mathrm{c}$-axis is normal to the surface of the substrate. The background increase toward the lower $2 \theta$ stems from the signal from the glass substrate.

The as-deposited sample shows that the observed peak is located at 34.03 degree with the FWHM of 0.91 degree. The reported (002) diffraction data for the bulk $\mathrm{ZnO}$ is 34.48 degree. The observed low-side shift suggests the lattice expansion along c-axis by 


\section{$1.27 \%$.}

On the other hand, the sample annealed at $600^{\circ} \mathrm{C}$ shows that the peak was observed at 34.48 degree that agrees well with the bulk $\mathrm{ZnO}$ data. The FWHM was reduced to 0.798 degree by the annealing. The similar results were reported when the substrate was $\mathrm{Si}$ wafer. The expansion along c-axis is due to the inclusion of excess oxygen elements into the deposited film as was reported [23]. The comparison with the results in the literature is interesting because the experimental condition was the same. The shift of the peak in this experiment was 0.45 degree that is smaller than 0.62 degree reported before. The FWHM in this experiment was 0.91 degree that is larger than 0.88 degree reported before. These two features lead us to conclude that, as for the glass substrate, the inhomogeneous strain is smaller but that the homogeneous strain is larger. Whether the substrate is crystalline or non-crystalline affects the structural state of the deposited film.

The annealing effect is considered next. Figure 2 shows the peak position of (002) line of the XRD spectrum as a function of annealing temperature. It tells us that

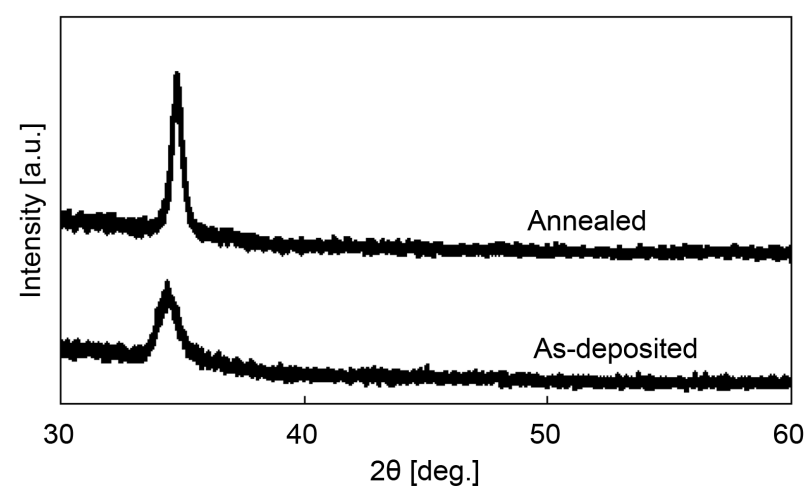

Figure 1. X-ray diffraction spectra from the samples that were as-deposited (lower) and annealed at $600^{\circ} \mathrm{C}$ (upper). Only one reflection peak assigned to (002) diffraction was observed in the both spectra.

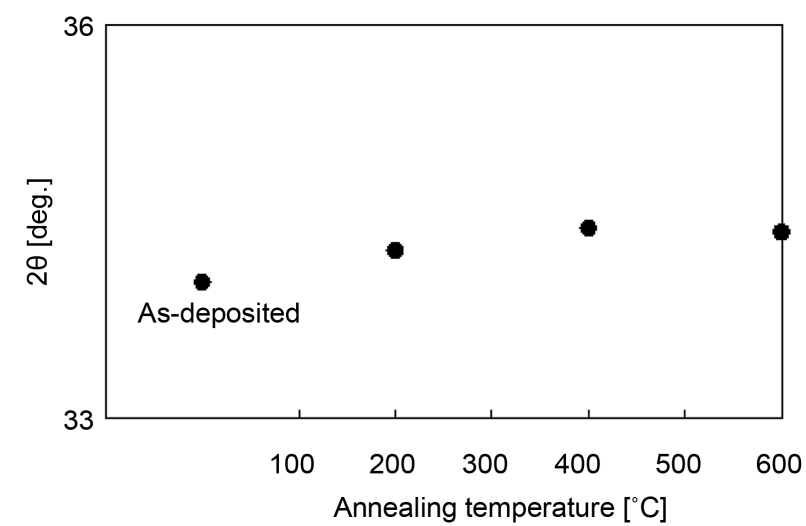

Figure 2. The dependence of the (002) peak position on the annealing temperature. The peak shift from 34.47 degree was completely vanished over $400^{\circ} \mathrm{C}$. 
annealing at greater than $400^{\circ} \mathrm{C}$ completely released the strain. The tendency is also observed in the sample deposited on the Si substrate [23]. Figure 3 shows, on the other hand, how the FWHM of the peak depends on the annealing temperature. The FWHM seems to reach the lowest limit at 0.5 degree as is also in the same manner as the Si substrate [23]. We cannot confirm further decrease of the FWHM with the higher temperature as shown in the literature because the annealing at the higher temperature cannot be loaded on the glass substrate. Although there is some influence of the kind of substrates on the deposited film, the annealing effects show in the same way in these two kinds of substrates. It means the post-deposition annealing is effective to restore the crystalline of $\mathrm{ZnO}$ films.

Abduev et al. reported $\mathrm{ZnO}$ films on glass with a DC magnetron sputtering method [21]. They reported the similar XRD diffraction patterns of only one peak corresponding to (002) diffraction. The $2 \theta$ was at 43.154 degree for the sample without heating the substrate during the deposition. This value is similar to ours. On the other hand, when the substrate was kept at $250^{\circ} \mathrm{C}$ during the deposition, the $2 \theta$ was at 34.45 degree that is similar to our annealed sample. However, the surface morphology is, as they reported, quite rough if the substrate temperature was $250^{\circ} \mathrm{C}$ during the deposition. Kim et al. reported the surface was smoothened by post-deposition annealing by preferential evaporation. In this point of view, the post-deposition annealing seems to be superior to heating substrates during the deposition. In our experiment, annealing was performed no higher than $600^{\circ} \mathrm{C}$, where Kim et al. at $800^{\circ} \mathrm{C}$. Actually the deposition at room temperature provided a smooth surface morphology as was reported by Kim et al.

Ozaki et al. reported that annealing below $700^{\circ} \mathrm{C}$ induced the c-axis orientation in $\mathrm{ZnO}$ films deposited by rf-sputtering [24]. Our results show the c-axis orientation without annealing. It shows that the DC sputtering is desirable to obtain a film of oriented crystal. Their result on photoluminescence at $2.5 \mathrm{eV}$ was noticeably improved even with the post-deposition annealing at $600^{\circ} \mathrm{C}$. It is hopeful for our sample to be applied to light emission.

Next interesting discussion is the comparison with the results reported by Hiramatsu

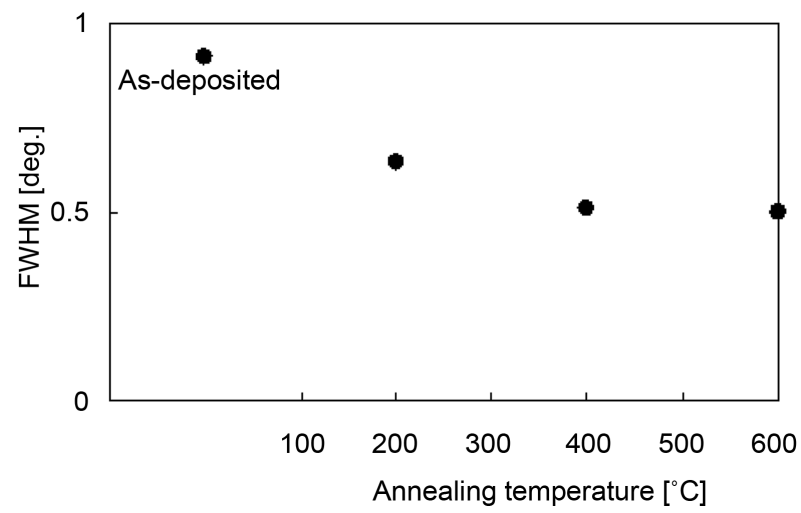

Figure 3. The FWHM of the (002) peak as a function of the annealing temperature. At $400^{\circ} \mathrm{C}$, the $\mathrm{FWHM}$ is lowered enough. 
et al. They reported the annealing induced crystallization only with the sample only when the film deposited under the chamber pressure of $0.5 \mathrm{~Pa}$ [25]. The film deposited under 7.0 Pa showed no influence by the annealing up to $350^{\circ} \mathrm{C}$. We assumed the possibility, in the former report [23], that the improvement of crystalline quality and stoichiometry of $\mathrm{ZnO}$ is induced by the diffusion of oxygen into silicon substrate. This assumption is hardly applied to in this article because the substrate is made of borosilicate glass.

The dependence of resistivity on annealing temperature is shown in Figure 4. Asdeposited sample showed around $500 \Omega \cdot \mathrm{cm}$. The post-deposition annealing has a large effect on decreasing the resistivity. At $600^{\circ} \mathrm{C}$, the resistivity comes down to $0.6 \Omega \cdot \mathrm{cm}$. The interesting point is that while the peak position and the FWHM of XRD spectrum is not so different between $400^{\circ} \mathrm{C}$ and $600^{\circ} \mathrm{C}$, the resistivity is nevertheless different by no less than two digits. We assume that the crystallite size is the one reason for the reduction of the resistivity. The annealing higher than $600^{\circ} \mathrm{C}$ is attractive but we need some ideas to avoid the deformation of glass substrate during annealing. It is possible conceivably that the softening of the substrate helps the enhancement of the crystalline quality. Along with the discussion above, it cannot be completely excluded that the larger FWHM in XRD pattern from the both samples non-annealed and annealed at $200^{\circ} \mathrm{C}$ is due to the smallness of the crystallites in the film.

Quemener et al. reported electronic properties of Al-doped $\mathrm{ZnO}$ deposited on p-type Si wafer by DC magnetron sputtering [22]. They observed the rectifying feature in I-V characteristics. They annealed their samples at from $100^{\circ} \mathrm{C}$ to $350^{\circ} \mathrm{C}$. Their data shows that the annealing suppresses the current density at both sides of bias voltage. They also describes that the annealing above $250^{\circ} \mathrm{C}$ gradually degrades the hetero structure. The reduction of resistivity is incompatible with that of hetero interface between $\mathrm{ZnO}$ and Si layers.

Finally, the DC sputtering has not been left for the research. We believe that it is valuable to investigate compound materials such as $\mathrm{ZnO}$ deposited by means of the DC sputtering. Further study is expected to reveal the film properties of $\mathrm{ZnO}$ in this way.

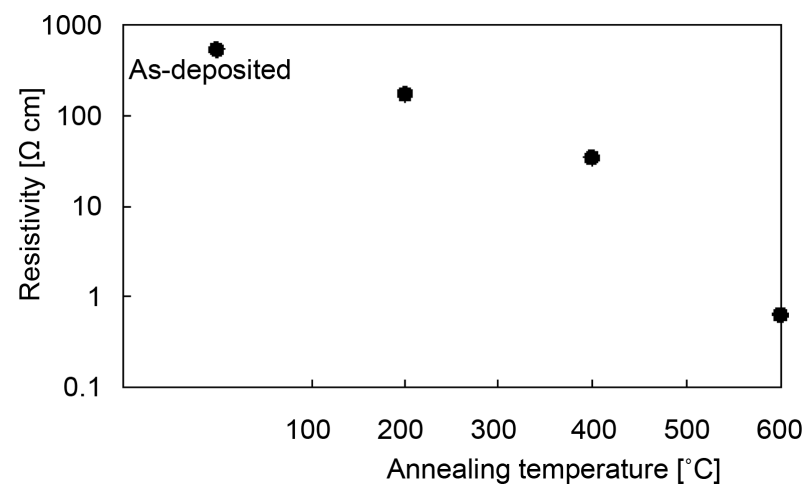

Figure 4. The resistivity of the deposited film as a function of the annealing temperature. It is noticeably decreases with the annealing temperature even over $400^{\circ} \mathrm{C}$. 


\section{Conclusion}

$\mathrm{ZnO}$ film was deposited on glass substrates by means of a DC sputtering technique. X-ray diffraction measurements show that the film consists of (001) oriented crystallites even at room temperature during the deposition in the similar way as a Si wafer is used as a substrate. Post-deposition annealing was performed up to $600^{\circ} \mathrm{C}$. The dependence of the peak shift of (002) diffraction and the FWHM of it revealed that the improvement in crystalline quality is saturated over $400^{\circ} \mathrm{C}$. However, the resistivity decreases monotonically with the annealing temperature even above $400^{\circ} \mathrm{C}$.

\section{References}

[1] Galli, G. and Coker, J.E. (1970) Epitaxial ZnO on Sapphire. Applied Physics Letters, 16, 439-441. http://dx.doi.org/10.1063/1.1653058

[2] Look, D.C. and Hemsky, J.W. (1999) Residual Native Shallow Donor in ZnO. Physical Review Letters, 82, 2552-2555. http://dx.doi.org/10.1103/PhysRevLett.82.2552

[3] Zhang, S.B., Wei, S.-H. and Zunger, A. (2001) Intrinsic n-Type versus p-Type Doping Asymmetry and the Defect Physics of ZnO. Physical Review B, 63, Article ID: 075205. http://dx.doi.org/10.1103/PhysRevB.63.075205

[4] Srikant, V. and Clarke, D.R. (1998) On the Optical Band Gap of Zinc Oxide. Journal of Applied Physics, 83, 5447-5451. http://dx.doi.org/10.1063/1.367375

[5] Klaus, E., Andreas, K. and Bernd, R. (2008) Transparent Conductive Zinc Oxide. Springer.

[6] Sang, B., Dairiki, K., Yamada, A. and Konagai, M. (1999) High-Efficiency Amorphous Silicon Solar Cells with $\mathrm{ZnO}$ as Front Contact. Japanese Journal of Applied Physics, 38, 49834988. http://dx.doi.org/10.1143/JJAP.38.4983

[7] Pearton, S.J., Abernathy, C.R., Thaler, G.T., Frazier, R.M., Norton, D.P., Ren, F., Park, Y.D., Zavada, J.M., Buyanova, I.A., Chen, W.M. and Hebard, A.F. (2004) Wide Bandgap GaNBased Semiconductors for Spintronics. Journal of Physics: Condensed Matter, 16, R209. http://dx.doi.org/10.1088/0953-8984/16/7/r03

[8] Bang, S., Lee, S., Park, J., Park, S., Ko, Y., Choi, C., Chang, H., Park, H. and Jeon, H. (2011) The Effects of Post-Annealing on the Performance of $\mathrm{ZnO}$ Thin Film Transistors. Thin Solid Films, 519, 8109-8113. http://dx.doi.org/10.1016/j.tsf.2011.05.048

[9] Yue, H., Wu, A., Feng, Y., Zhang, X. and Li, T. (2011) Structures and Properties of the Al-Doped ZnO Thin Films Prepared by Radio Frequency Magnetron Sputtering. Thin Solid Films, 519, 5577-5581. http://dx.doi.org/10.1016/j.tsf.2011.03.026

[10] Furuta, M., Hiramatsu, T., Matsuda, T., Furuta, H. and Hirao, T. (2007) Effect of Energetic Particle Bombardment on Microstructure of Zinc Oxide Films Deposited by rf Magnetron Sputtering. Japanese Journal of Applied Physics, 46, 4038-4041. http://dx.doi.org/10.1143/JJAP.46.4038

[11] Look, D.C., Reynolds, D.C., Litton, C.W., Jones, R.L., Eason, D.B. and Cantwell, G. (2002) Characterization of Homoepitaxial p-Type ZnO Grown by Molecular Beam Epitaxy. Applied Physics Letters, 81, 1830-1832. http://dx.doi.org/10.1063/1.1504875

[12] Kim, M.S., Kim, D.Y., Cho, M.Y., Nam, G., Kim, S., Lee, D.-Y., Kim, S.-O. and Leem, J.-Y. (2012) Effects of Buffer Layer Thickness on Properties of ZnO Thin Films Grown on Porous Silicon by Plasma-Assisted Molecular Beam Epitaxy. Vacuum, 86, 1373-1379. http://dx.doi.org/10.1016/j.vacuum.2012.01.006

[13] Craciun, V., Elders, J., Gardeniers, J.G.E. and Boyd, I.W. (1994) Characteristics of High 
Quality ZnO Thin Films Deposited by Pulsed Laser Deposition. Applied Physics Letters, 65, 2963-2965. http://dx.doi.org/10.1063/1.112478

[14] Chirakkara, S. and Krupanidhi, S.B. (2012) Study of n-ZnO/p-Si (100) Thin Film Heterojunctions by Pulsed Laser Deposition without Buffer Layer. Thin Solid Films, 520, 58945899. http://dx.doi.org/10.1016/j.tsf.2012.05.003

[15] Ataev, B.M., Bagamadova, A.M., Mamedov, V.V. and Omaev, A.K. (1999) Thermally Stable, Highly Conductive, and Transparent ZnO Layers Prepared In Situ by Chemical Vapor Deposition. Materials Science and Engineering. B, 65, 159-163. http://dx.doi.org/10.1016/S0921-5107(99)00166-X

[16] Xie, Y., Madel, M., Zoberbier, T., Reiser, A., Jie, W., Neuschl, B., Biskupek, J., Kaiser, U., Feneberg M. and Thonke, K. (2012) Enforced c-axis Growth of ZnO Epitaxial Chemical Vapor Deposition Films on $\alpha$-Plane Sapphire. Applied Physics Letters, 100, Article ID: 182101. http://dx.doi.org/10.1063/1.4709430

[17] Ahmad, A. and Alsaad, A. (2006) Optical Properties of ZnO Related to the Dc Sputterin Power. European Physical Journal B, 52, 41-46. http://dx.doi.org/10.1140/epjb/e2006-00272-0

[18] Hata, T., Minamikawa, T., Morimoto, O. and Hada, T. (1979) DC Reactive Magnetron Sputtered ZnO Films. Journal of Crystal Growth, 47, 171-176.

http://dx.doi.org/10.1016/0022-0248(79)90239-2

[19] Suchea, M., Christoulakis, S., Katsarakis, N., Kitsopoulos, T. and Kiriakidis, G. (2007) Comparative Study of Zinc Oxide and Aluminum Doped Zinc Oxide Transparent Thin Films Grown by Direct Current Magnetron Sputtering. Thin Solid Films, 515, 6562-6566. http://dx.doi.org/10.1016/j.tsf.2006.11.151

[20] Lee, J., Kim, Y., Song, P., Lee, J., Kim, Y. and Son, C. (2008) Characteristic of Ga-Doped $\mathrm{ZnO}$ Films Deposited by DC Magnetron Sputtering with a Sintered Ceramic ZnO: Ga Target. Journal of the Korean Physical Society, 53, 416-420.

[21] Abduev, A., Akhmedov, A., Asvarov, A. and Sulyanov, S. (2008) Investigations of Synthesis Mechanisms of ZnO Thin Films in DC Magnetron Sputter Processes. Journal of the Korean Physical Society, 53, 59-62.

[22] Quemener, V., Vines, L., Monakhov, E.V. and Svensson, B.G. (2011) Electronic Properties of $\mathrm{n}-\mathrm{ZnO}(\mathrm{Al}) / \mathrm{p}-\mathrm{Si}$ Heterojunction Prepared by Dc Magnetron Sputtering. Thin Solid Films, 519, 5763-5766. http://dx.doi.org/10.1016/j.tsf.2010.12.204

[23] Ohmukai, M., Nakagawa, T. and Matsumoto, A. (2015) Oxygen Surplus to Zn in ZnO Films Deposited by Means of Direct Current Sputtering. Journal of Nanoelectronics and Optoelectronics, 10, 65-68. http://dx.doi.org/10.1166/jno.2015.1696

[24] Ozaki, K. and Gomi, M. (2002) Strong Ultraviolet Photoluminescence in Polycrystalline ZnO Sputtered Films. Japanese Journal of Applied Physics, 41, 5614-5617. http://dx.doi.org/10.1143/JJAP.41.5614

[25] Hiramatsu, T., Furuta, M., Furuta, H., Matsuda, T. and Hirao, T. (2007) Influence of Thermal Annealing on Microstructures of Zinc Oxide Films Deposited by Rf Magnetron Sputtering. Japanese Journal of Applied Physics, 46, 3319-3323. http://dx.doi.org/10.1143/JJAP.46.3319 
Submit or recommend next manuscript to SCIRP and we will provide best service for you:

Accepting pre-submission inquiries through Email, Facebook, LinkedIn, Twitter, etc. A wide selection of journals (inclusive of 9 subjects, more than 200 journals)

Providing 24-hour high-quality service

User-friendly online submission system

Fair and swift peer-review system

Efficient typesetting and proofreading procedure

Display of the result of downloads and visits, as well as the number of cited articles

Maximum dissemination of your research work

Submit your manuscript at: http://papersubmission.scirp.org/

Or contact msce@scirp.org 